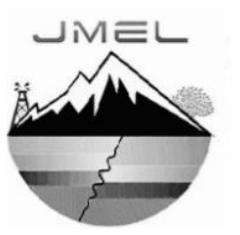

\title{
Identifikasi Keberadaan Rongga sebagai Pemicu Amblesan (Sinkhole) Berdasarkan Data Geologi dan Geolistrik Di Daerah Bedoyo, Kecamatan Ponjong, Kabupaten Gunung Kidul
}

\author{
Al Hussein Flowers Rizqi ${ }^{1, a)}$ dan Waskita Bambang Murti Yudhana ${ }^{1)}$ \\ 1) Program Studi Teknik Geologi, Fakultas Teknologi Mineral, Institut Teknologi Nasional Yogyakarta \\ a) Email korespondensi: alhussein@sttnas.ac.id
}

\begin{abstract}
ABSTRAK
Kejadian amblesan di Kecamatan Ponjong masih sering terjadi terutama pada musim penghujan. Daerah penelitian terletak pada Karst Gunung Sewu, tepatnya di Desa Bedoyo, Kecamatan Ponjong, Kabupaten Gunung Kidul. Penelitian ini bertujuan untuk memetakan kondisi geologi dan bawah permukaan. Identifikasi keberadaan rongga pada batuan ditentukan berdasarkan nilai resistivitas berdasarkan gambaran bawah permukaan. Dari gambaran bawah permukaan 2D/3D juga dapat diidentifikasi jenis amblesan dan genesanya. Metode penelitian menggunakan pemetaan geologi dan bawah permukaan menggunakan geolistrik Schlumberger. Kondisi bawah permukaan pada lokasi penelitian berdasarkan hasil kajian geolistrik dapat diinterpretasikan adanya zona-zona rongga (cavity zones) yang diduga sebagai pemicu amblesan di permukaan. Pada daerah penelitian di Desa Bedoyo dan sekitarnya memiliki 2 (dua) jenis tipe amblesan berdasarkan genesanya yaitu: tipe dropout sinkhole dan suffosion sinkhole. Pada amblesan dengan tipe suffosion sinkhole dipengaruhi oleh adanya struktur geologi berupa sesar naik. Hasil dari pemodelan geologi dan amblesan di daerah penelitian didapatkan hasil berupa zona rawan amblesan yang terbagi menjadi 3 zona yaitu zona rawan, sedang, dan aman. Zona rawan amblesan mencakup Desa Sigorejo, Gombong, Pucanganom dan Desa Bedoyo, zona Sedang mencakup pada Desa Sumbergiri dan Desa Karangasem, sedangkan untuk wilayah zona rendah mencakup daerah di Dusun Asem Lulang.
\end{abstract}

Kata Kunci: Amblesan (sinkhole); geolistrik; ponjong; rongga

\section{ABSTRACT}

The incidence of subsidence in Ponjong District is still common, especially during the rainy season. The research area is located in Gunung Sewu Karst, to be precise in Bedoyo Village, Ponjong District, Gunung Kidul Regency. This study aims to map the geological and subsurface conditions. Identification of the presence of cavities in rock is determined based on the resistivity value based on the subsurface image. From the 2D / 3D subsurface image, the type of subsidence and genes can also be identified. The research method uses geological and subsurface mapping using geoelectrics Schlumberger. The subsurface conditions at the research location based on the results of the geoelectric study can be interpreted as the presence ofcavity zones which are thought to trigger subsidence on the surface. The research area in Bedoyo Village and its surroundings has 2 (two) types of subsidence based on the genes, namely:type sinkhole dropout and suffosion sinkhole. A subsidence with type is suffosion sinkhole influenced by the presence of a geological structure in the form of an upward fault. The results of the geological modeling and subsidence in the research area showed that the zone is prone to subsidence which is divided into 3 zones, namely the vulnerable, moderate, and safe zones. The zone prone to subsidence includes the villages of Sigorejo, Gombong, Pucanganom and Bedoyo Village, the moderate zone includes Sumbergiri and Karangasem villages, while the low zone includes the area in Asem Lulang hamlet.

Keywords: Cavity; geolectrical; ponjong; sinkhole

\section{PENDAHULUAN}

Amblesan atau dikenal sebagai sinkhole pernah terjadi di kisaran 2018 - 2020 di Kecamatan Ponjong, Gunung Kidul. Amblesan yang terjadi memiliki diameter maupun kedalaman lubang yang bervariasi. Amblesan tanah muncul sebagai permasalahan geologi dapat terjadi secara alamiah ataupun disebabkan oleh pengaruh aktivitas manusia. Salah satu pemicu alamiah terjadinya amblesan tanah adalah berupa proses pelarutan batuan bawah permukaan oleh air yang umum terjadi pada batuan karbonat (batugamping dan dolomit), endapan garam dan gypsum (Allen,1984). Baik secara alamiah maupun akibat pengaruh aktivitas manusia, kecepatan dan tingkat amblesan dikontrol oleh kondisi litologi, iklim, vegetasi dan waktu serta dipicu oleh beberapa proses seperti pelarutan batuan, erosi mekanik bawah permukaan, kompresi atau kompaksi, pengaliran airtanah, getaran, dan penyusutan (Allen, 1984 ; Glopper dan Ritzema, 1994).

Sifat amblesan tanah yang lambat, bertahap dan meluas membuat bencana ini jarang dikenali dan disadari oleh masyarakat. Dampak amblesan telah tampak nyata seperti kerusakan bangunan, jalan, kawassan industri dan lainnya (Abidin dkk., 2013; Marfai dan King, 2008; Arbiyakto dan Kadaryanto, 2002). Namun belum ada tindak lanjut khusus 
yang dilakukan untuk mengurangi dampak-dampaknya. Kurangnya kesadaran masyarakat dan pemangku kepentingan disebabkan oleh kurangnya pengetahuan mengenai mekanisme amblesan serta besarnya dampak ekonomi akibat amblesan. Upaya penanganan bencana amblesan diperlukan untuk mengurangi dampak yang telah terjadi dan bermanfaat bagi pemulihan lingkungan sekitar.

Kejadian amblesan pernah dikaji oleh beberapa peneliti terdahulu. Widyaningtyas dkk (2014) mengkaji di Kecamatan Semanu, sebelah barat Kecamatan Ponjong menggunakan data permukaan dan metode AHP (Analytic Hierarchy Process. Kontrol litologi merupakan faktor dominan yang mempengaruhi kejadian amblesan di daerah batuan karbonat. Daerah penelitian termasuk ke dalam dataran tinggi Wonosari, tepatnya di Desa Bedoyo, Kecamatan Ponjong, Kabupaten Gunung Kidul. Secara stratigrafi, termasuk ke dalam Formasi Wonosari-Punung (Tmwl) (Gambar 1) secara dominan. Secara geologi, daerah ini tersusun oleh betuan karbonat meliputi batugamping kristalin, batugamping klastis, hingga batugamping napalan-tufaan serta batupasir yang secara lokal tersingkap di daerah Wediwutah dan sekitarnya (Samodra, 2016). Formasi ini berumur Miosen Tengah hingga Akhir. (Surono dkk,1992). Namun, secara setempat di daerah Pucang Anom dijumpai tuf yang diduga berasal dari Formasi Semilir yang berumur N4-N5 (Miosen Awal) (Rizqi dan Fatimah, 2020)

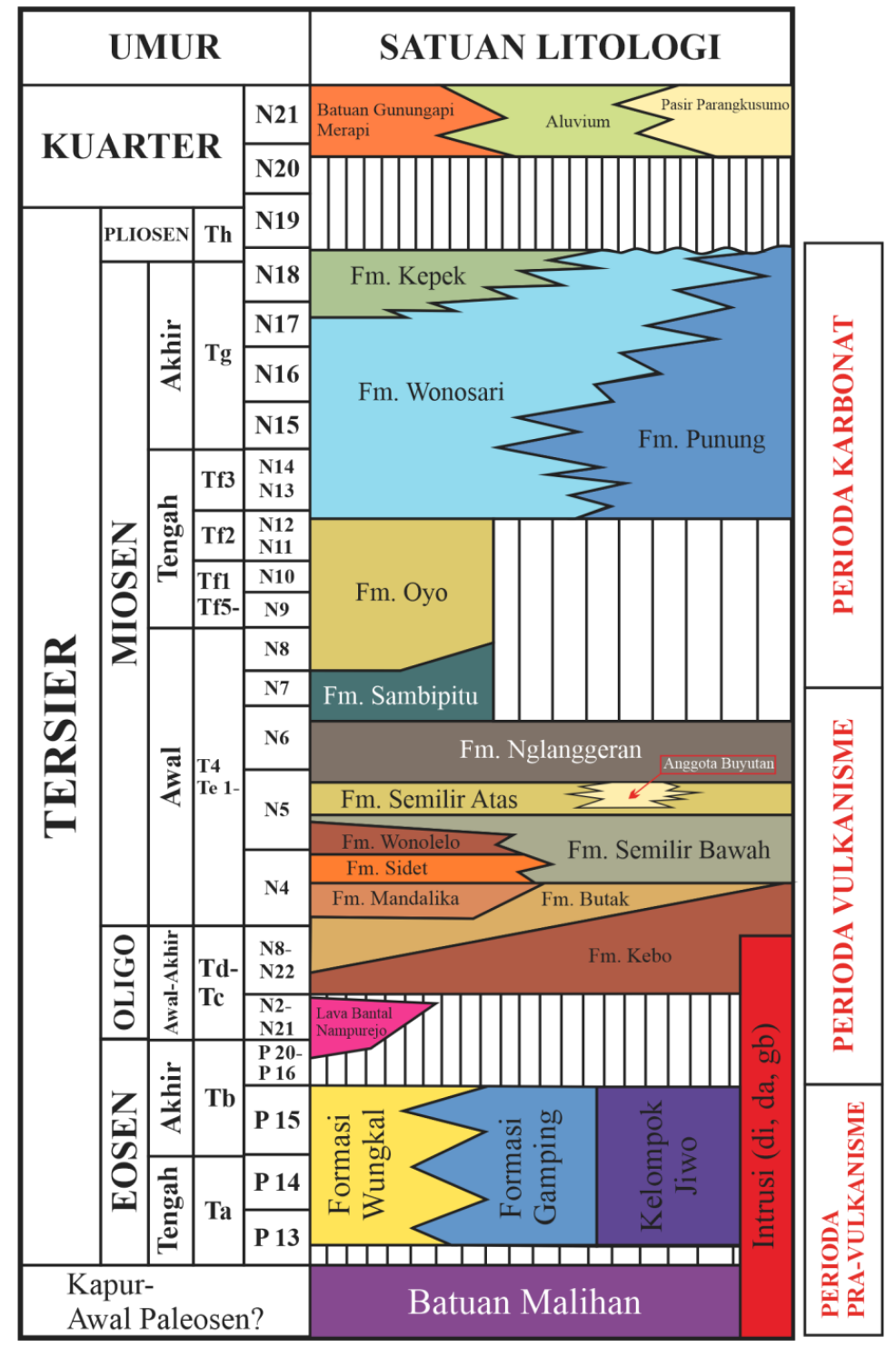

Gambar 1. Stratigrafi daerah penelitian, lokasi penelitian terletak pada Formasi Wonosari (Surono dkk,1992),

Metode lain yang digunakan untuk mengkaji amblesan adalah metode geolistrik. Penelitian mengenai amblesan menggunakan metode geolistrik pernah dikaji oleh Andi dan Setiahadiwibowo (2020), di daerah Nusakambangan. Kajian tersebut mendapatkan hasil bahwa amblesan terjadi pada nilai resistivitas tinggi dan terletak di kedalaman 10 - 
20 meter dari permukaan tanah. Hasil kajian rongga atau amblesan juga dijumpai pada batuan karbonat di daerah Kalimantan Selatan (Aurelia, 2016). Kajian penelitian ini merupakan kajian lanjutan dari Yudhana dkk (2020) yang meneliti secara umum mengenai amblesan di Ponjong. Penelitian ini bertujuan lebih spesifik dalam mengkaji kondisi geologi dan bawah permukaan daerah penelitian. Tipe dan genesa amblesan diidentifikasi berdasarkan klasifikasi Waltham dkk (2005). Kondisi bawah permukaan dimodelkan secara 3D untuk dijadikan acuan dilakukannya mitigasi terhadap amblesan di daerah penelitian.

Pemetaan geologi permukaan dirasa masih belum bisa untuk menentukan zona dan potensi bahaya amblesan dengan akurat. Oleh karena itu, dalam penelitian ini perlu ditunjang dengan menggunakan kajian geofisika untuk memetakan kondisi geologi bawah permukaan di daerah penelitian. Pemetaan bawah permukaan ini dilakukan untuk mendapatkan bentukan gambaran vertikal rongga bawah permukaan di lokasi penelitian yang berpotensi terjadinya amblesan. Pemetaan geologi permukaan dirasa masih belum bisa untuk menentukan zona dan potensi bahaya amblesan dengan akurat. Adanya peta bahaya amblesan yang menjadi luaran penelitian diharapkan dapat memberikan arahan untuk pengembangan wilayah berbasis bencana geologi yang tepat untuk wilayah Kecamatan Ponjong, Gunung Kidul, Yogyakarta. Informasi kondisi bawah permukaan, litologi dan tingkat curah hujan diperlukan untuk mitigasi amblesan pada suatu daerah. Observasi lapangan, evaluasi data sekunder, pengumpulan data morfologi, litologi, kelurusan geologi, keberadaan sinkhole dan kejadian amblesan perlu dilakukan untuk mencapai tujuan tersebut.

\section{METODE}

Metode penelitian yang digunakan adalah pemetaan geologi permukaan (geological surface mapping) dan metode bawah permukaan (geolistrik). Metode pemetaan geologi permukaan ini meliputi pengamatan, pemerian, dan pengukuran langsung di lapangan pada kenampakan data - data serta kondisi geologi yang tersingkap, berupa data morfologi, singkapan batuan, struktur geologi, dan potensi geologi lingkungan. Sedangkan metode pemetaan bawah permukaan meliputi pengambilan data lapangan, pemrosesan dan pemodelan baik sacara 2D maupun 3D. Tahapan pertama yaitu melakukan kajian pustaka dari peneliti terdahulu dan peta geologi regional serta peta topografi sebagai acuan dalam perencanaan penelitian yang efektif. Pemetaan secara umum dan menyeluruh tentang keadaan daerah penelitian. Pengamatan pada tahap ini dapat dirinci sebagai berikut : Orientasi medan untuk pengambilan data, dilanjutkan dengan observasi kondisi geologi berupa kondisi geomorfologi, liniasi struktur geologi, dan litologi. Analisis petrografi dilakukan pada beberapa lokasi terpilih untuk melihat persentase komposisi batuan dan keberadaan rongga.

Pengambilan data geofisika di lapangan menggunakan metode geolistrik konfigurasi Schlumberger. Perangkat keras yang digunakan adalah satu set Resistivitymeter, Global Positioning System (GPS), dan buku kerja. Akuisisi data dilakukan dalam lima lintasan pada tiga desa yang berbeda (Tabel 1).

Tabel 1. Lokasi Pengambilan data geolistrik

\begin{tabular}{llll}
\hline $\mathbf{N o}$ & Lokasi & Sounding & Kordinat UTM \\
\hline $\mathbf{1}$ & Desa Kenteng & 1-SLB-BDY & \\
\hline $\mathbf{2}$ & Dusun Asem Lulang & 2-SLB-BDY & 49S 4683189115835 \\
$\mathbf{3}$ & Dusun Ngalas Ombo & 3-SLB-BDY & 49S 4697019114033 \\
$\mathbf{4}$ & Desa Bedoyo Lor & 4-SLB-BDY & 49S 471170 9114721 \\
$\mathbf{5}$ & Desa Bedoyo Kidul & 5-SLB-BDY & 49S 4718889112852 \\
\hline
\end{tabular}

Metode geolistrik tahanan jenis merupakan suatu metode geofisika yang memanfaatkan sifat tahanan jenis untuk mempelajari keadaan bawah permukaan bumi. Metode ini dilakukan dengan menggunakan arus listrik searah yang diinjeksikan melalui dua buah elektroda arus ke dalam bumi, lalu mengamati potensial yang terbentuk melalui dua buah elektroda potensial yang berada di tempat lain (Telford dkk, 1990). Konfigurasi elektroda yang digunakan dalam penelitian ini adalah metode resistivitas dengan konfigurasi Schlumberger. Metode ini dilakukan dengan cara mengkondisikan spasi antar elektrode potensial adalah tetap sedangkan spasi antar elektroda arus berubah secara bertahap. Metode ini menempatkan elektroda potensial MN pada bentangan bentangan tertentu, sedangkan elektroda arus $\mathrm{AB}$ selalu dipindahkan sesuai dengan bentangan yang dipilih. Penempatan bentangan elektroda potensial MN dan elektroda arus $\mathrm{AB}$ diutamakan memenuhi syarat bahwa jarak MN/2 adalah 1/5 jarak AB/2. Bila posisi jarak elektroda $\mathrm{AB}$ diubah menjadi lebih besar maka tegangan listrik yang terjadi pada elektroda $\mathrm{MN}$ ikut berubah sesuai dengan 
informasi jenis batuan yang ikut terinjeksi arus listrik pada kedalaman yang lebih besar lihat Gambar 2. Pada dasarnya hantaran listrik batuan yang kering lebih rendah dari pada batuan yang berisi airtanah dan bila elektrolit yang ada dalam pori-pori batuan bersifat konduktif garam ataupun kadar mineral yang tinggi maka akan menaikkan daya hantar listrik batuan tersebut

Tahapan selanjutnya adalah tahapan analisis studio meliputi analisis data permukaan dan bawah permukaan. Analisis data permukaan berupa pembuatan peta geologi regional, geomorfologi, analisis kelurusan. Data litologi (penamaan batuan secara megaskopis) akan menghasilkan peta geologi daerah penelitian. Tahap analisis studio dilakukan pada analisis struktur geologi. Struktur geologi yang terdapat pada daerah penelitian diinterpretasikan berdasarkan pengamatan dan pengkajian peta DEMNAS dengan menggunakan software Geomatica 2015 dan Arcgis 10.3, peta geologi regional, peta topografi dan data hasil survei pendahuluan.

Data bawah permukaan berupa pengolahan data hasil survei geofisika (geolistrik) menggunakan software Progress dan dimodelkan secara 3 dimensi menggunakan Software Rockworks. Berdasarkan hasil proses pengolahan data tersebut akan didapatkan gambaran kondisi bawah permukaan daerah penelitian sehingga dapat diidentifikasi titik potensi terjadi amblesan pada daerah penelitian. Analisis laboratorium dilakukan untuk melihat keberadaan rongga berdasarkan kenampakan mikroskopis pada sayatan petrografi.

Tahapan akhir penelitian berupa intepretasi dan evaluasi secara komprehensif terhadap data geomorfologi, stratigrafi, litologi maupun struktur geologi sehingga dapat dievaluasi dengan berdasarkan teori dan hasil peneliti terdahulu. Data yang akan dievaluasi secara rinci yaitu Peta lokasi titik pengamatan, Peta geologi daerah penelitian, dan hasil rekonstruksi model bawah permukaan (3D) sehingga kita dapat mengidentifikasi titik rawan potensi amblesan.

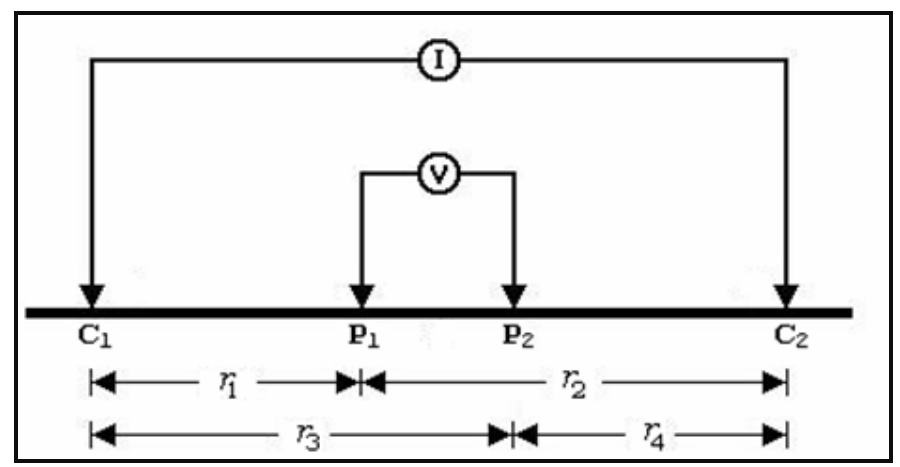

Gambar 2. Konfigurasi Schlumberger homogen dengan tahanan jenis $\rho$ (Bahri, 2005, dalam Zubaidah dkk, 2008)

\section{HASIL DAN PEMBAHASAN}

\subsection{Geologi Daerah Penelitian}

Geologi daerah penelitian dikaji dalam beberapa aspek yang meliputi aspek geomorfologi, stratigrafi, dan struktur geologi. Secara umum kondisi geomorfologi daerah penelitian termasuk ke dalam kerucut - kerucut (bukit Kars) dan berupa dataran di bagian barat laut (Gambar 3). Gambar 3 memperlihatkan pembagian satuan geomorfologi pada daerah penelitian mengacu pada klasifikasi dari van Zuidam-Cancelado (1979), pembagian satuan tersebut berdasarkan geometri, genesa, dan letak geografi daerah penelitian. 
36 ISSN 2549-7197 (cetak), ISSN 2549-564X

(online) JMEL, Volume 4 Nomor 2, 2020

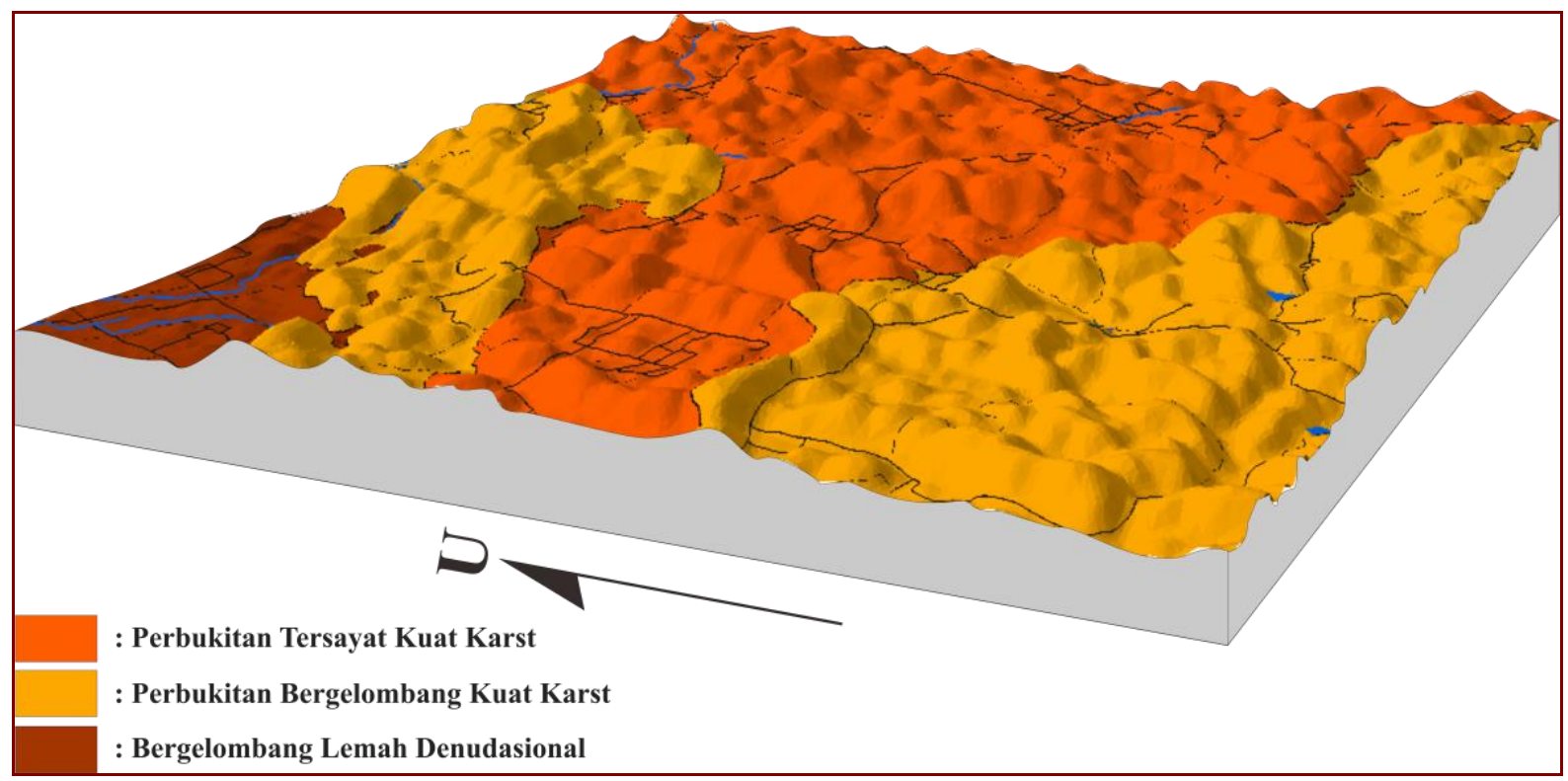

Gambar 3. Geomorfologi daerah penelitian dalam model 3 dimensi dipandang dari sisi Barat daya

Berdasarkan data-data yang didapatkan di lapangan dan dari interpretasi pola kontur pada daerah penelitian, peneliti membagi satuan geomorfologi ialah:

1. Satuan Geomorfologi Bergelombang Lemah Denudasional

2. Satuan Geomorfologi Perbukitan - Tersayat Kuat Kars

3. Satuan Geomorfologi Perbukitan Bergelombang Kuat kars

Stratigrafi daerah penelitian dikembangkan dengan mengacu pada peta geologi regional menurut Surono, dkk (1992). Dari kajian stratigrafi pada daerah penelitian dijumpai beberapa litologi, antara lain batugamping terumbu, batugamping berlapis, dan tuf. Analisis umur batuan mengacu pada penelitian terdahulu. Umur batugamping terumbu dan batugamping berlapis N 14 - N19 dan tuf Semilir berumur Miosen Awal (Rizqi dan Fatimah, 2020). Analisis petrografi dilakukan pada lima sayatan terpilih (Tabel 2). Tabel 2 akan memperlihatkan komposisi batua berdasarkan kandungan fosil, mikrit, kalsit, dan rongga.

Tabel 2. Persentase dan komposisi batugamping di daerah penelitian :

\begin{tabular}{|c|c|c|c|c|c|c|c|}
\hline \multirow[t]{2}{*}{ No } & \multirow[t]{2}{*}{ Kode } & \multirow[t]{2}{*}{ Jenis batugamping } & \multicolumn{4}{|c|}{ Komposisi (\%) } & \multirow[t]{2}{*}{ Nama Petrografi } \\
\hline & & & Fosil & Kalsit & Mikrit & Rongga & \\
\hline 1 & BDY01 & Chalky (klastik) & 36.5 & - & 42.5 & 21.00 & Packestone \\
\hline 2 & BDY02 & Kristalin (nonklastik) & 51.75 & 8.75 & 34.25 & 5.25 & $\begin{array}{l}\text { Packestone } \\
\text { Floatstone }\end{array}$ \\
\hline 3 & BDY03 & Kristalin (nonklastik) & 34 & 6.25 & 50.55 & 9.25 & Packestone \\
\hline 4 & BDY05 & Kristalin (nonklastik) & 41.25 & 20.5 & 37.75 & 0.50 & Packestone \\
\hline 5 & BDY06 & Kristalin (nonklastik) & 72.25 & 5.75 & 6.5 & 15.5 & $\begin{array}{l}\text { Grainstone } \\
\text { Rudstone }\end{array}$ \\
\hline
\end{tabular}

Berdasarkan komposisi di atas daerah penelitian lebih didominasi oleh batugamping kristalin (packestone) (Dunham, 1962) yang hampir memiliki porositas (rongga). Di beberapa tempat juga dijumpai adanya Floatstone dan Rudstone (Embry dan Klovan, 1971). Keberadaan rongga pada batugamping disinyalir dapat menjadi cikal bakal adanya amblesan di daerah penelitian. Keberadaan rongga tersebut banyak tercermin di lapangan sebagai lapies pada batugamping. Amblesan yang terjadi pada permukaan diinterpretasikan dikontrol oleh struktur geologi. Struktur geologi diinterpretasi melalui citra DEMNAS dan kajian lapangan. Citra DEMNAS menunjukkan Pola kelurusan serta terdapat offset 
topografi dari daerah penelitian yang dimungkinkan adanya kontrol struktur berupa kekar-kekar yang intensif maupun berupa antiklin, sinklin, dan sesar atau patahan. Pada peta DEMNAS terlihat pola kelurusan yang dominan berarah Baratlaut-Tenggara, serta sebagian pola kelurusan relatif berarah barat-timur, yang diilustrasikan pada diagram rose (lihat Gambar 4). Adapun Gambar 4 memperlihatkan kelurusan yang dianggap sebagai kelurusan struktur geologi atau slip lineament yang mengontrol pada daerah penelitian, serta kelurusan bukit, kelurusan sungai, dan kelurusan lembah. Berdasarkan dari analisis pola kelurusan pada daerah penelitian didapatkan hasil bahwa pola kelurusan umum di daerah penelitian berarah baratlaut-tenggara. Hal tersebut memperkuat bahwa struktur daerah penelitian adalah salah satu faktor pengontrol terjadinya amblesan pada salah satu titik kejadian amblesan di daerah penelitian.

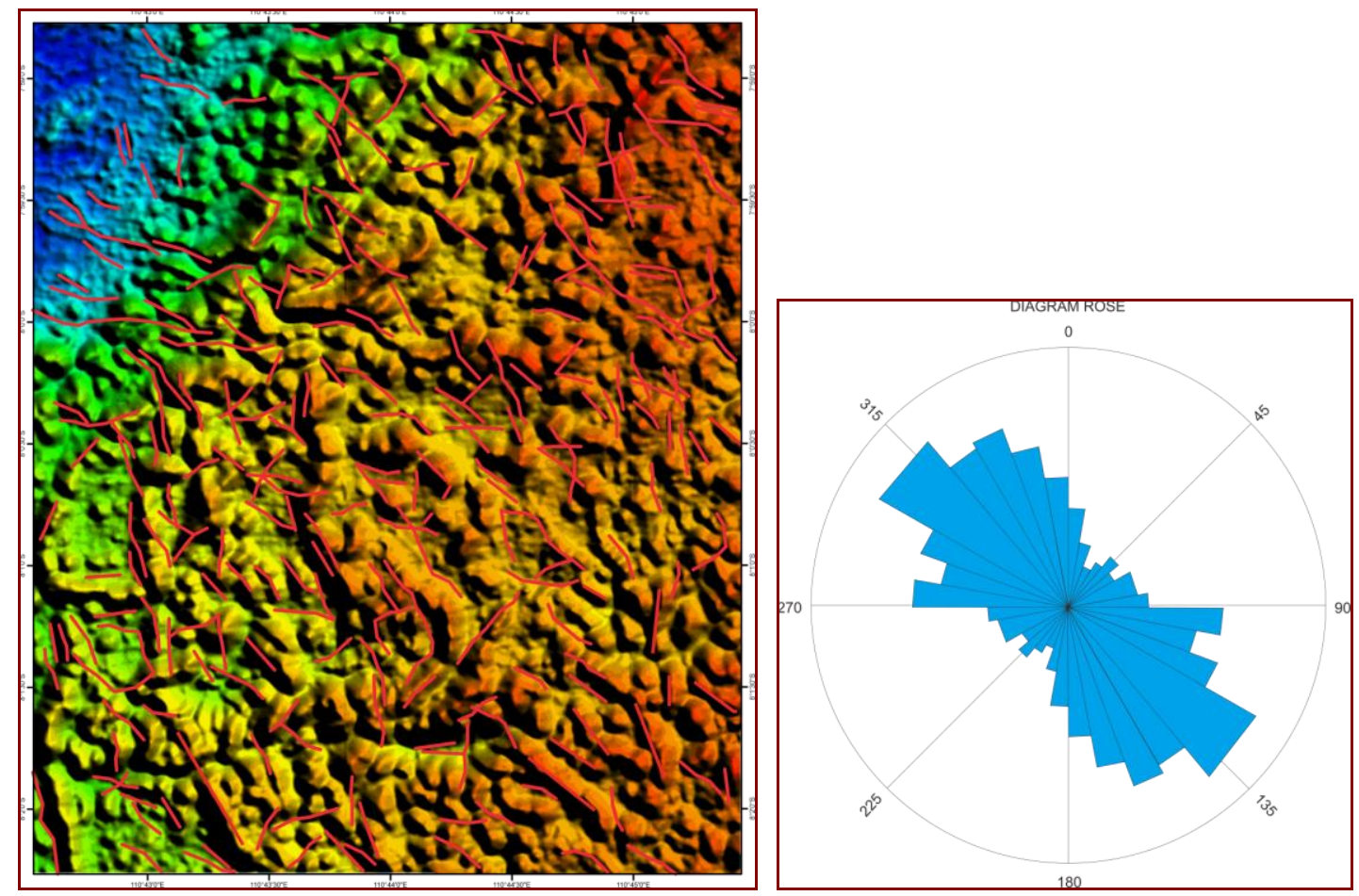

Gambar 4. Peta Lineasi menggunakan peta DEMNAS memperlihatkan kelurusan arah dominan baratlaut-tenggara

Selain faktor geologi, curah hujan menjadi salah satu faktor ekternal yang sangat penting sebagai penyebab terjadinya amblesan. Hal tersebut dikarenakan litologi pada daerah penelitian bersifat mudah larut. Berdasarkan hasil penelitian didapatkan hasil bahwa kejadian amblesan yang terjadi pada daerah lokasi penelitian cenderung muncul pada musim penghujan dengan curah hujan yang sangat intensif dan biasanya terjadi pada awal tahun antara bulan Januari - Maret dan pada akhir tahun yaitu pada bulan November - Desember (BMKG, 2019) (Gambar 5).

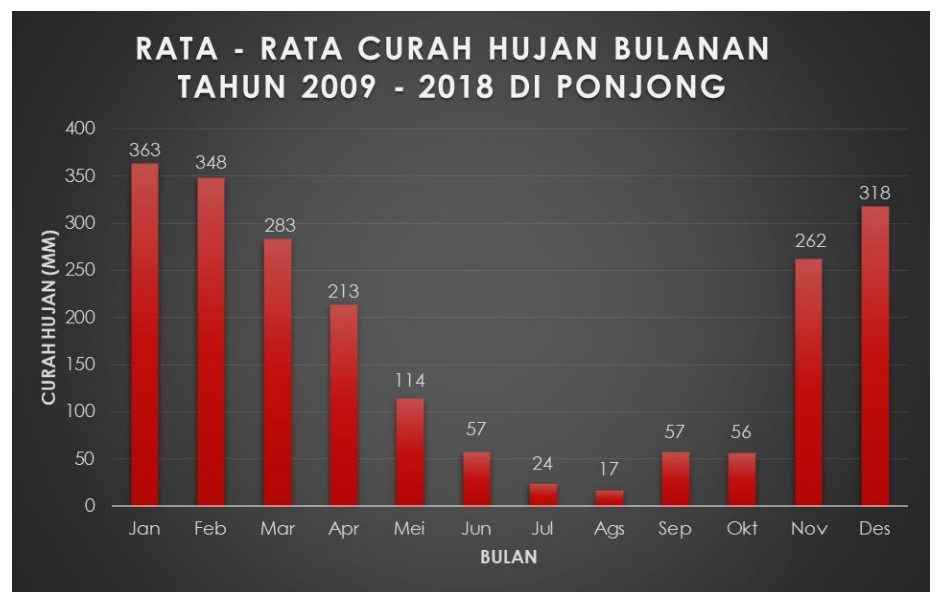

Gambar 5. Grafik curah hujan di Kecamatan Ponjong (Sumber :BMKG) 
38 ISSN 2549-7197 (cetak), ISSN 2549-564X

(online) JMEL, Volume 4 Nomor 2, 2020

\subsection{Identifikasi keberadaan amblesan (sinkhole) pada permukaan}

Waltham, dkk, (2005) menyebutkan bahwa kejadian amblesan di daerah karst berkaitan dengan proses pembentukan sinkhole. Proses pembentukan Sinkhole dapat dibagi menjadi enam genesa yaitu; solution sinkhole, collapse sinkhole, dropout sinkhole, buried sinkhole, caprock sinkhole, dan suffusion sinkhole. Dari hasil penelitian dan pengambilan data primer dilapangan yang didasarkan pada penjelasan genesa pembentukan amblesan tersebut maka daerah penelitian terdapat 4 jenis amblesan dari 6 kejadian pada titik yang berbeda dengan kontrol yang berbeda-beda pula, yaitu sebagai berikut:

\subsubsection{Amblesan Drop out sinkhole}

Amblesan jenis ini diduga terjadi jika lapisan penutup merupakan endapan atau tanah yang kohesif, maka amblesan yang terjadi kemungkinan bertipe drop out sinkhole. Litologi di sekitar kejadian amblesan tersebut didominasi oleh batugamping, baik berupa batugamping terumbu ataupun batugamping berlapis. Kejadian amblesan ini beberapa sering terjadi di dekat telaga dan pemukiman penduduk pada daerah penelitian lihat Gambar 6. Amblesan yang berada di daerah penelitian ini diduga sebagai amblesan dengan genesa yang sama seperti Drop out doline. Hal tersebut terlihat dilapangan dengan kenampakan soil (lapisan penutup) pada bagian atas yang tebalnya $\pm 2-3$ meter yang kemudian dibawahnya terdapat batuan yang sudah berongga. Batuan yang sudah berongga tersebut diperkirakan adalah batugamping yang sifatnya batuan mudah larut oleh air. Tingginya intensitas hujan membuat batuan tersebut sangat intensif terjadinya proses pelarutan.
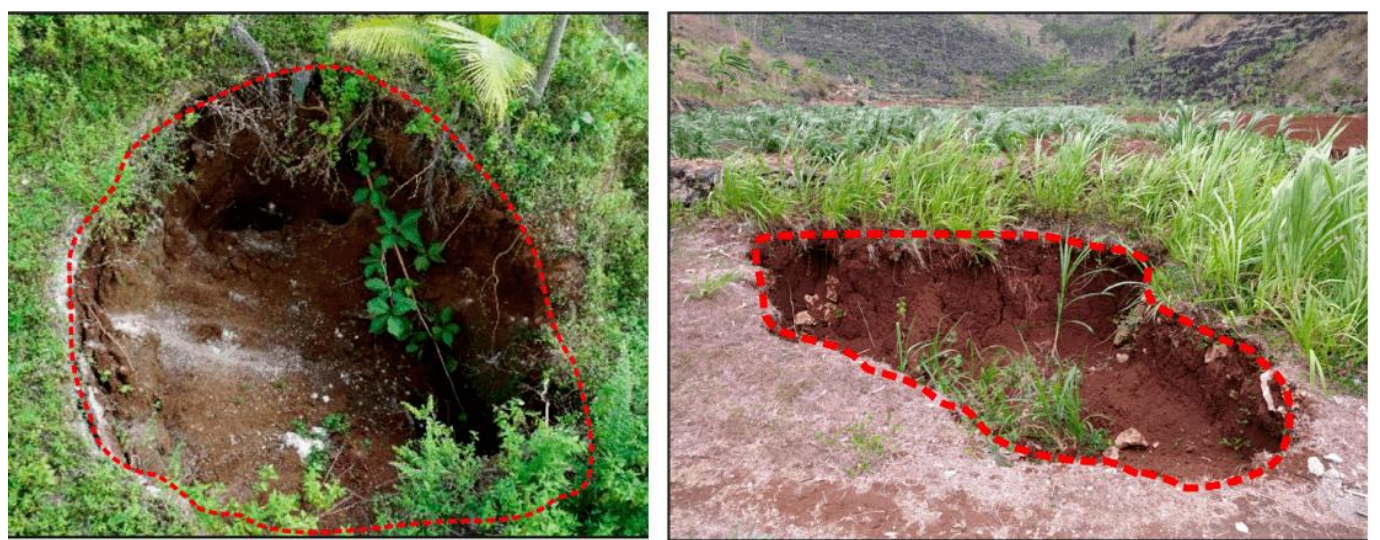

Gambar 6. Kejadian amblesan di Desa Kenteng (kiri); amblesan yang terjadi pada Pucanganom (kanan)

\subsubsection{Amblesan Suffosion Sinkhole}

Amblesan jenis ini diduga terjadi jika lapisan penutup tersusun atas endapan pasiran, maka amblesan yang terjadi bertipe suffosion sinkhole. Endapan pasiran diinterpretasikan sebagai endapan berukuran pasir yang berasal dari sedimentasi sungai di utara daerah penelitian (Waskita, 2020). Amblesan jenis ini terdapat pada beberapa lokasi yaitu Desa Sigorejo, Pringluang, Bedoyo Kidul dan Asem Lulang lihat Gambar 7. Kenampakan soil (lapisan penutup) pada bagian atas yang tebalnya $\pm 2-4 \mathrm{~m}$ dan berbentuk cekung. Pada lokasi di Desa Bedoyo kidul terdapat faktor lain yang dijumpai di lapangan yang diduga menjadi salah satu penyebab amblesan tipe ini. Faktor tersebut adalah struktur geologi berupa sesar naik. Sesar naik ini ditunjukkan dengan adanya singkapan tuf Semilir yang berumur lebih tua (Miosen Awal) (Rizqi dan Sugarbo, 2020) tersingkap ke permukaan. Bidang sesar menunjukkan arah cenderung ke arah baratlaut tenggara. Sesar tersebut searah dengan lokasi amblesan yang terjadi di daerah penelitian. Keberadaan sesar tersebut diinterpretasikan menjadi penyebab adanya rekahan dan kemudian membuat lapisan penutup turun secara perlahan. 

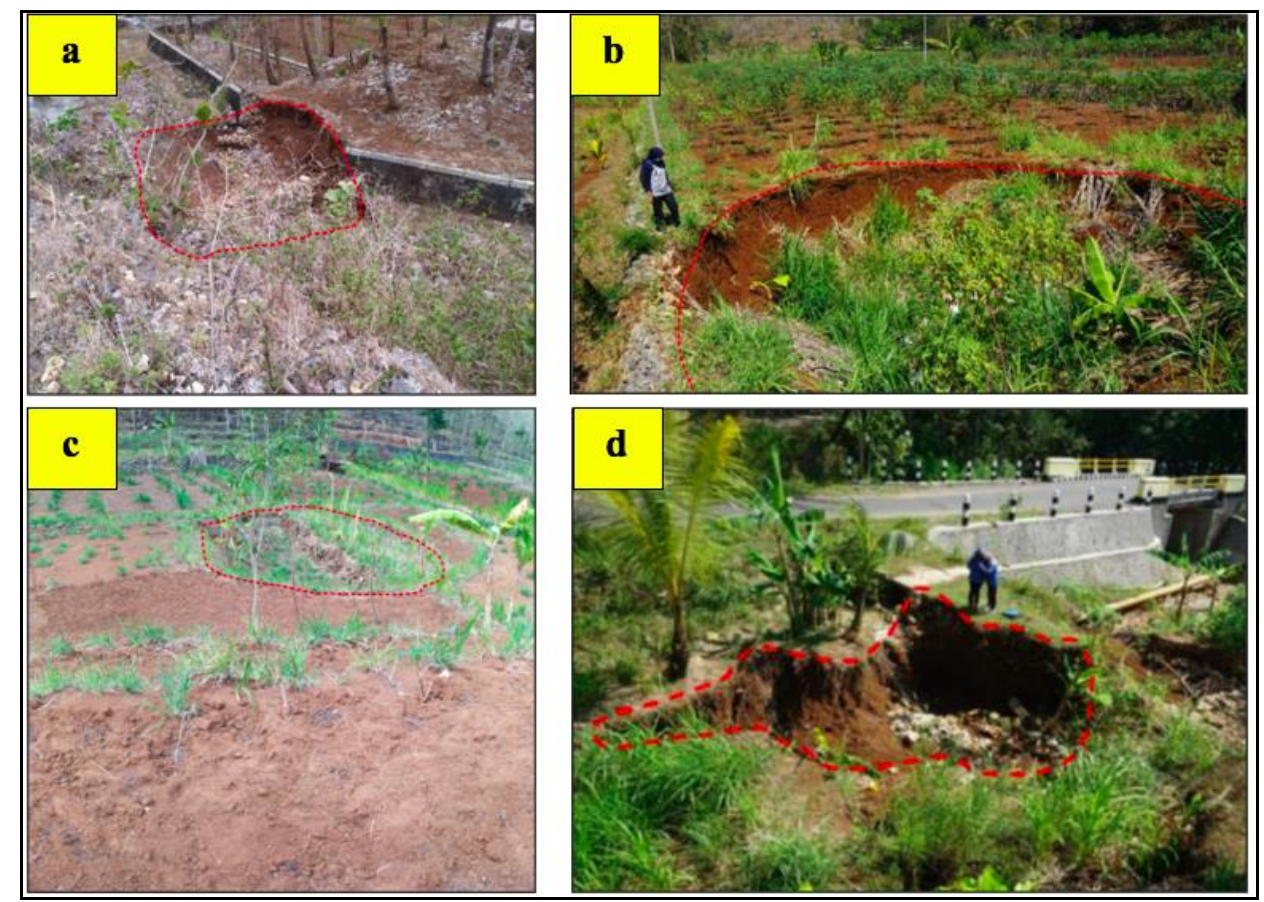

Gambar 7. a) Kejadian amblesan di Desa Sigorejo; b) Amblesan di Dusun Pringluang; c) Amblesan di Desa Bedoyo Kidul; d) Amblesan di Desa Asem Lulang

\subsection{Identifikasi keberadaan rongga berdasarkan data geolistrik}

Hasil dari pengambilan data geologi daerah penelitian kemudian diperkuat dengan data geolistrik untuk mengetahui kondisi bawah permukaan di daerah penelitian.. Pengambilan data geolistrik pada lokasi penelitian sebagian besar dilakukan pada daerah dengan kondisi amblesan di permukaan. Amblesan dipermukaan dengan dimensi yang berbedabeda mulai dari 2 meter sampai dengan 10 meter. Lokasi 1 di Desa Kenteng, lokasi 2 yang berada di Dusun Asem Lulang, lokasi 3 Berada di Desa Bedoyo, lokasi 4 berada di Dusun Bedoyo Lor dan lokasi 5 berada di Desa Bedoyo Kidul. Hasil dari pengambilan data geolistrik dengan konfigurasi Schlumberger tersebut kemudian diolah menggunakan software Progress. Kondisi geologi permukaan pada titik pengambilan data geolistrik didominasi oleh batugamping terumbu, batugamping berlapis dan soil pada permukaan. Kondisi litologi permukaan ini menjadi acuan untuk menginterpretasikan hasil dari akuisisi dan pengolahan data geolistrik.

\subsubsection{Identifikasi rongga dan litologi di Dusun Kenteng}

Hasil pengukuran geolistrik di Dusun Kenteng dengan capaian kedalaman yang bisa diinterpretasikan sedalam 100 meter. Adapun litologi penyusun daerah ini adalah sebagai berikut

a) Lapisan 1 dengan nilai tahanan jenis $0.02-42,89(\Omega \mathrm{m})$ pada kedalaman 0-3 meter dan dengan ketebalan lapisan berkisar antara 3 meter berupa soil.

b) Lapisan 2 yaitu pada kedalaman 4 -18 meter dijumpai sebuah lapisan dengan nilai tahanan jenis $1,07 \Omega \mathrm{m}$ yang dapat diinterpretasikan sebagai zona rongga (cavity zone)

c) Pada lapisan 3 yaitu pada kedalaman 4-25 meter (ketebalan 21 meter) dijumpai lapisan dengan nilai tahanan jenis berkisar antara 2,62 $(\Omega \mathrm{m})$ yang diinterpretasikan sebagai rongga.

d) Pada lapisan 4 dengan kedalaman 25-52 meter dijumpai lapisan setebal \pm 27 meter dengan nilai tahanan jenis sebesar $20,81(\Omega \mathrm{m})$ yang diinterpretasikan sebagai lapisan batupasir.

e) Pada lapisan 5 yaitu pada kedalaman 52-100 meter dijumpai lapisan dengan nilai tahanan jenis yaitu $1.58(\Omega \mathrm{m})$ yang diinterpretasikan sebagai lapisan batupasir tufan.

Kondisi geologi bawah permukaan di Daerah dusun Kenteng tersusun oleh litologi berupa soil, batupasir dan juga batupasir tufan. Lapisan 2 lokasi ini yaitu pada kedalaman 5-25 m dengan nilai tahanan jenis 1,07-2,62 $\Omega \mathrm{m}$ diduga merupakan zona rongga (cavity zone). Zona rongga pada titik ini memiliki ketebalan yang cukup tebal. Hal tersebut sangat berbahaya apabila hasil dari data ini benar. Hal tersebut dapat menyebabkan lubang amblesan permukaan yang cukup besar. 


\subsubsection{Identifikasi rongga dan litologi di Dusun Asem Lulang}

Hasil pengukuran geolistrik di Dusun Asem Lulang dengan capaian kedalaman yang bisa diinterpretasikan sedalam 55 meter. Adapun litologi penyusun daerah ini adalah sebagai berikut:

a) Lapisan 1 dengan nilai tahanan jenis 12,82-17,78 $\Omega \mathrm{m}$ pada kedalaman 0-4 meter dan dengan ketebalan lapisan berkisar antara 4 meter berupa soil.

b) Pada lapisan 2 yaitu pada kedalaman 4-10 meter (ketebalan 6 meter) ditemukan lapisan dengan nilai tahanan jenis berkisar antara 27,39 $\Omega \mathrm{m}$ yang diinterpretasikan sebagai batupasir.

c) Pada lapisan 3 dengan kedalaman 10-14 meter ditemukan lapisan setebal \pm 4 meter dengan nilai tahanan jenis sebesar berkisar antara 6,53-10,12 $\Omega \mathrm{m}$ yang diinterpretasikan sebagai lapisan rongga.

d) Pada lapisan 4 yaitu pada kedalaman 14-29 meter ditemukan lapisan dengan nilai tahanan jenis yaitu 82,54-214,19 $\Omega m$ yang diinterpretasikan sebagai lapisan batugamping berlapis.

e) Pada lapisan 5 yaitu pada kedalaman 29-55 meter ditemukan lapisan dengan nilai tahanan jenis yaitu 400,11$16417,57 \Omega m$ yang diinterpretasikan sebagai lapisan batugamping terumbu.

Kondisi bawah permukaan di Dusun Asem Lulang ini tersusun oleh litologi berupa soil, batupasir tufan, batugamping berlapis dan juga batugamping terumbu. Pada Lapisan 3 di lokasi ini yaitu pada kedalaman 10-14 meter dengan nilai tahanan jenis 6,53-10,12 $\Omega$ m diduga merupakan zona rongga (cavity zone).

\subsubsection{Identifikasi rongga dan litologi di Dusun Ngalas Ombo}

Hasil pengukuran geolistrik di Desa Ngalas Ombo dengan panjang bentangan total 400 meter dengan capaian kedalaman yang bisa diinterpretasikan sedalam 100 meter. Adapun litologi penyusun daerah ini adalah sebagai berikut:

a) Lapisan 1 dengan nilai tahanan jenis 15,33 $\Omega$ m pada kedalaman 0-2 meter dan dengan ketebalan lapisan berkisar antara 2 meter berupa soil.

b) Pada lapisan 2 yaitu pada kedalaman 2-5 meter (ketebalan 3 meter) dijumpai lapisan dengan nilai tahanan jenis 6,40 $\Omega m$ yang diinterpretasikan sebagai zona rongga (cavity zone)

c) Lapisan 3 yaitu pada kedalaman 5-9 meter dijumpai sebuah lapisan dengan nilai tahanan jenis sebesar 9,80 $\Omega \mathrm{m}$ yang juga diinterpretasikan sebagai zona rongga (cavity zone)

d) Pada lapisan 3 dengan kedalaman 10-14 meter dijumpai lapisan setebal \pm 4 meter dengan nilai tahanan jenis sebesar berkisar antara $147,15 \Omega \mathrm{m}$ yang diinterpretasikan sebagai lapisan batugamping berlapis.

e) Pada lapisan 4 yaitu pada kedalaman 14-100 meter dijumpai lapisan dengan nilai tahanan jenis yaitu 665,58-5465,35 $\Omega m$ yang diinterpretasikan sebagai lapisan batugamping terumbu.

Kondisi geologi bawah permukaan Desa Bedoyo ini tersusun oleh litologi berupa soil, batupasir dan juga batupasir tufan. Lapisan 2 lokasi ini yaitu pada kedalaman 2-9 meter dengan nilai tahanan jenis 6,40-9,80 $\Omega$ m diduga merupakan zona rongga (cavity zone).

\subsubsection{Identifikasi rongga dan litologi di Dusun Bedoyo Lor}

Hasil pengukuran geolistrik di Dusun Bedoyo Lor dengan capaian kedalaman yang bisa diinterpretasikan sedalam 70 meter. Adapun litologi penyusun daerah ini adalah sebagai berikut:

a) Lapisan 1 dengan nilai tahanan jenis 3,22-41,57 $\Omega \mathrm{m}$ pada kedalaman 0-4 meter dan dengan ketebalan lapisan berkisar antara 4 meter berupa soil.

b) Lapisan 2 yaitu pada kedalaman 4-7 meter (ketebalan 3 meter) dijumpai lapisan dengan nilai tahanan jenis 17,26 $\Omega \mathrm{m}$ yang diinterpretasikan sebagai batupasir.

c) Lapisan 3 dengan kedalaman 7-25 meter dijumpai lapisan setebal \pm 18 meter dengan nilai tahanan jenis sebesar berkisar antara 61,02-91,13 $\Omega$ m yang diinterpretasikan sebagai lapisan batugamping berlapis.

d) Lapisan 4 yaitu pada kedalaman 25-39 meter dijumpai lapisan dengan nilai tahanan jenis yaitu 24,61-27,75 $\Omega \mathrm{m}$ yang diinterpretasikan sebagai lapisan batupasir tufan.

e) Lapisan 5 yaitu pada kedalaman 39-47 meter dijumpai lapisan dengan nilai tahanan jenis yaitu 16,23 $\Omega \mathrm{m}$ yang diinterpretasikan sebagai lapisan batupasir.

f) Lapisan 6 yaitu pada kedalaman 47-70 meter dijumpai lapisan dengan nilai tahanan jenis yaitu 4,16 $\Omega \mathrm{m}$ yang diinterpretasikan sebagai lapisan rongga.

Kondisi geologi bawah permukaan daerah ini tersusun oleh litologi berupa soil, batupasir, batugamping berlapis dan juga batupasir tufan. Lapisan 11 lokasi ini yaitu pada kedalaman 47-70 m dengan nilai tahanan jenis yaitu 4,16 $\Omega \mathrm{m}$ diduga merupakan zona rongga (cavity zone). 


\subsubsection{Identifikasi rongga dan litologi di Dusun Bedoyo Kidul}

Hasil pengukuran geolistrik di Dusun Asem Lulang dengan capaian kedalaman yang bisa diinterpretasikan sedalam 55 meter. Adapun litologi penyusun daerah ini adalah sebagai berikut:

a) Lapisan 1 dengan nilai tahanan jenis 12,88-18,89 $\Omega \mathrm{m}$ pada kedalaman 0-4 meter dan dengan ketebalan lapisan berkisar antara 4 meter berupa soil.

b) Pada lapisan 2 yaitu pada kedalaman 4-10 meter (ketebalan 6 meter) ditemukan lapisan dengan nilai tahanan jenis berkisar antara 27,39 $\Omega \mathrm{m}$ yang diinterpretasikan sebagai batupasir.

c) Pada lapisan 3 dengan kedalaman 10-14 meter ditemukan lapisan setebal \pm 4 meter dengan nilai tahanan jenis sebesar berkisar antara 6,53-10,12 $\Omega$ m yang diinterpretasikan sebagai lapisan rongga.

d) Pada lapisan 4 yaitu pada kedalaman 14-29 meter ditemukan lapisan dengan nilai tahanan jenis yaitu 82,54-214,19 $\Omega m$ yang diinterpretasikan sebagai lapisan batugamping berlapis.

e) Pada lapisan 5 yaitu pada kedalaman 29-55 meter ditemukan lapisan dengan nilai tahanan jenis yaitu 400,11$16417,57 \Omega m$ yang diinterpretasikan sebagai lapisan batugamping terumbu.

Kondisi bawah permukaan daerah ini tersusun oleh litologi berupa soil, batupasir dan juga batupasir tufan. Lapisan 5 dan 6 lokasi ini yaitu pada kedalaman 10-14 m dengan nilai tahanan jenis 6,53-10,12 $\Omega$ m diduga merupakan zona rongga (cavity zone). Keberadaan rongga di daerah penelitian secara dominan berada pada kedalaman 5 - 20 meter, terkecuali di Desa Bedoyo Lor (4-SLB-BDY) berada pada kedalaman 45 meter lihat Gambar 8.

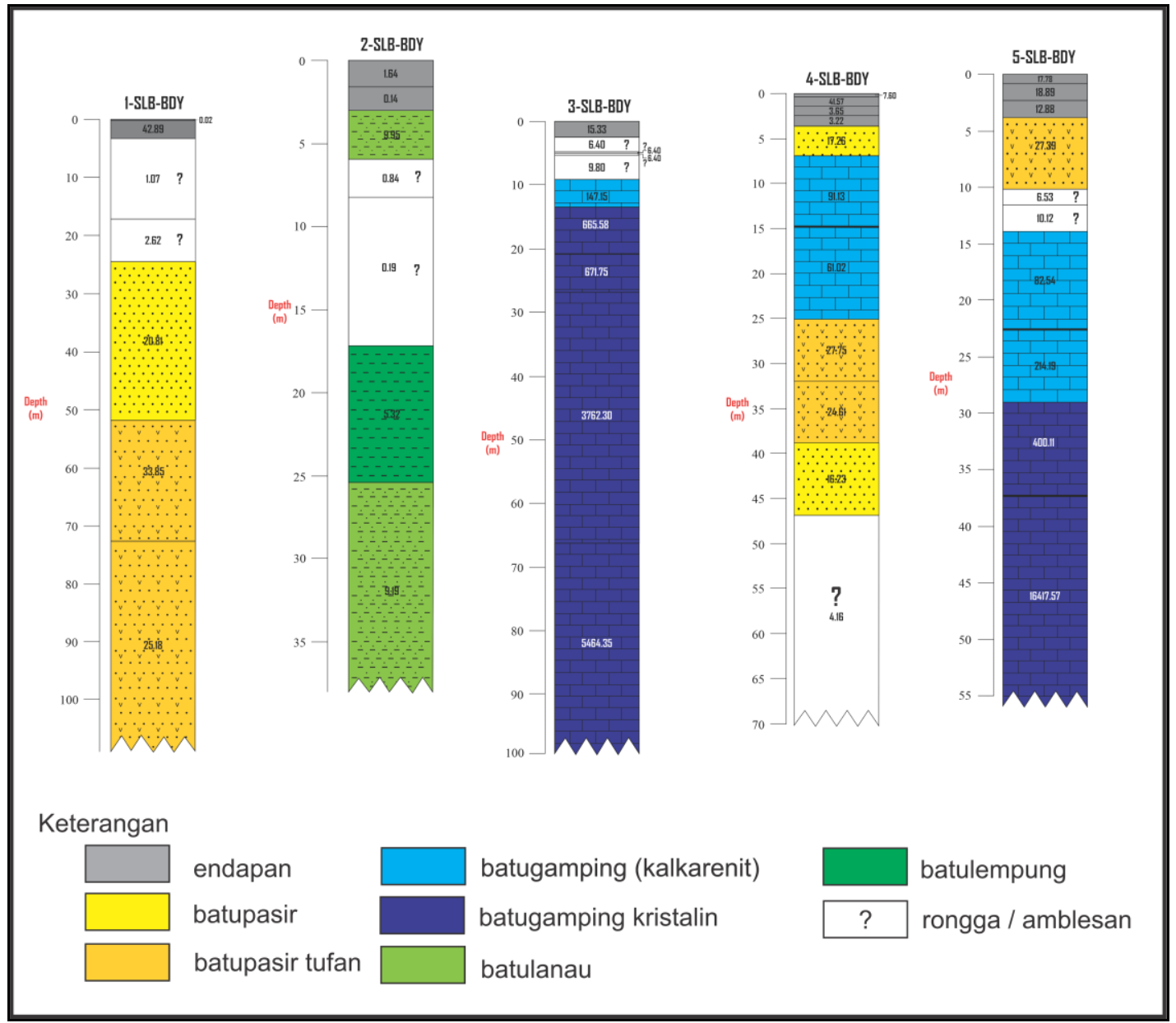

Gambar 8. Pemodelan geologi permukaan dan bawah permukaan menunjukkan adanya korelasi antara amblesan di permukaan dan data rongga pada bawah permukaan

Dari hasil kajian geologi permukaan dan bawah permukaan berupa geolistrik dengan menggunakan konfigurasi Schlumberger kemudian dilakukan pemodelan dengan menggunakan software Rockworks dan juga Software Arcgis didapatkan hasil seperti Gambar 9 yang dikorelasikan dengan kejadian amblesan yang sudah ada. Hasil pemodelan 
bawah permukaan diinterpretasikan bahwa adanya sungai bawah tanah yang membuat lapisan bawah permukaan menjadi berongga secara perlahan dan berangsur. Hal tersebut yang membuat terjadinya amblesan permukaan. Akan tetapi, tidak semua amblesan pada lokasi penelitian ini diakibatkan karena adanya sungai bawah permukaan tersebut.

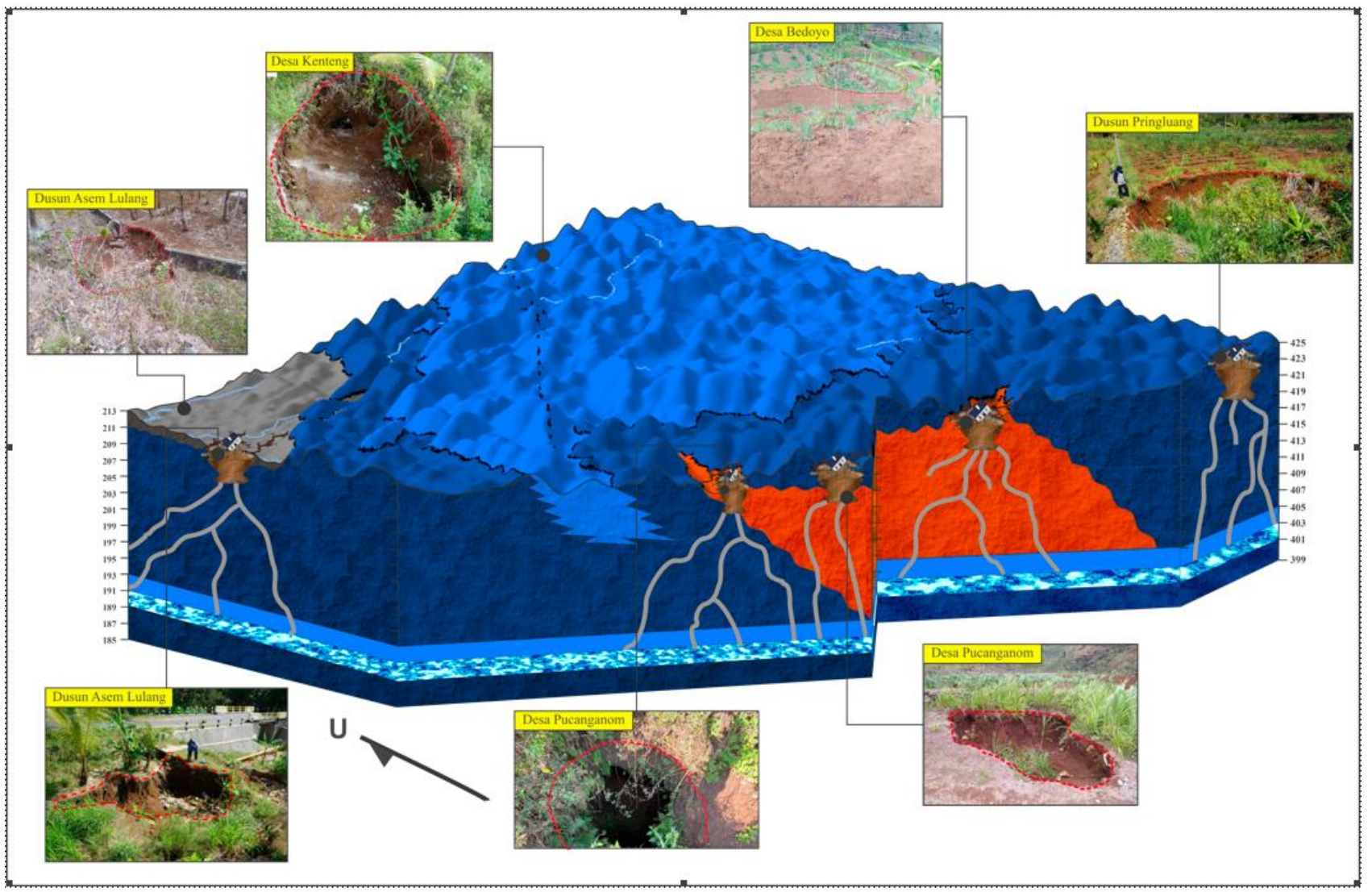

Gambar 9. Pemodelan geologi permukaan dan bawah permukaan menunjukkan adanya korelasi antara amblesan di permukaan dan data rongga pada bawah permukaan

\subsection{Zonasi Rawan Amblesan di daerah Penelitian}

Daerah penelitian yang didapatkan hasil berupa Peta Zonasi Rawan Amblesan di daerah penelitian yang terbagi dalam 3 zona yaitu zona rawan dengan prosentase 55\% yang meliputi Desa Kenteng, Sigorejo, Gombong, Pucanganom dan Desa Bedoyo, zona sedang dengan prosentase 38\% mencakup Desa Sumbergiri dan Desa Karangasem dan zona rendah dengan prosentase 7\% mencakup Dusun Asem Lulang dan Desa Ponjong. Pembagian tersebut diambil berdasarkan kondisi geologi, tata guna lahan, litologi dan kondisi bawah permukaan pada daerah penelitian tersebut yang dapat dilihat pada Gambar 10.

Hasil dari pemodelan zona rawan amblesan pada daerah Desa Bedoyo dan sekitarnya menjadi sebuah gambaran bahwasanya bahaya amblesan pada daerah penelitian cukup berbahaya dikarenakan mencakup lebih dari $50 \%$ dari keseluruhan daerah penelitian dangat rawan tejadi amblesan yang cukup intensif. Jika suatu saat curah hujan pada daerah penelitian ini sangat intensif maka kejadian ambesan sangat mungkin untuk terjadi pada berbagai lokasi dengan kondisi bawah permukaan yang sudah berongga.

Dampak dari terjadinya amblesan ini sangat besar terhadap kehidupan masyarakat di sekitar zona rawan amblesan seperti kerugian matrial, dampak psikologis (merasa khawatir), kerusakan bangunan, kegagalan pondasi dan juga penurunan badan jalan. Berdasarkan dari dampak amblesan yang sangat besar tersebut kita dapat meminimalisir kerugian yang akan terjadi seperti melakukan survei bawah permukaan menggunakan metode geofisika, melakukan mitigasi bencana amblesan, memperbaiki sistem tata ruang berbasis rawan bencana amblesan, dan melakukan grouting pada zona-zona amblesan yang sudah terjadi tidak akan meluas.

Apabila pengkajian bawah permukaan pada daerah sekitar lokasi penelitian dilakukan dengan skala besar maka dapat menjadi sebuah acuan dalam menanggulangi dampak kerugian dari kejadian amblesan ini. Indikasi amblesan permukaan 
dapat dikenali dengan mengamati kondisi sekitar seperti munculnya rekahan-rekahan kecil (Gambar 11), sungai pemukaan yang tiba-tiba menghilang (sinking streams), dan turunnya muka tanah secara perlahan. Hal tersebut dapat terjadi akibat dari beberapa faktor seperti jenis batuan, adanya sungai bawah tanah (underground rivers), curah hujan, dan juga aktivitas manusia seperti konstruksi bawah tanah dan juga kegiatan pertambangan bawah permukaan (underground mining).

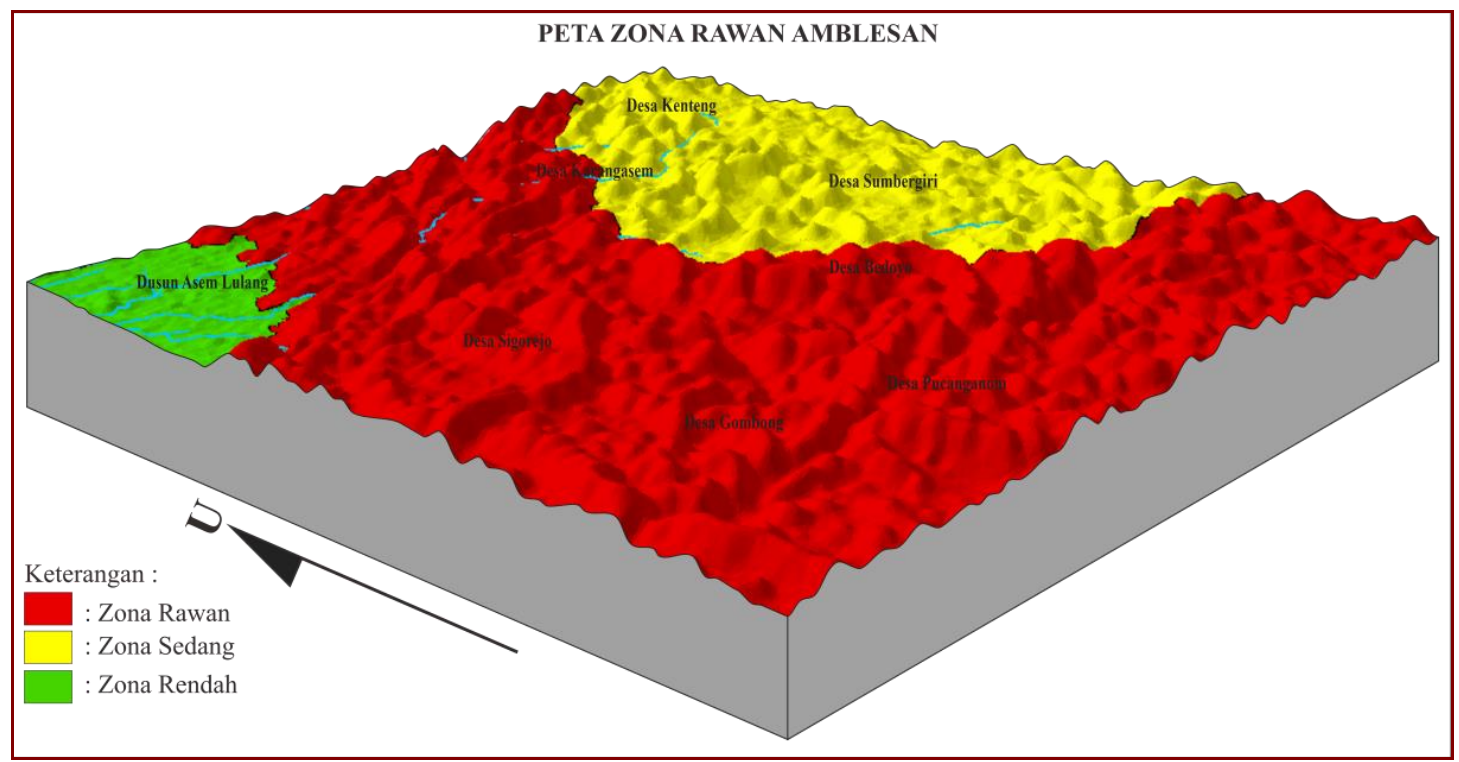

Gambar 10. Zonasi Potensi Amblesan di daerah penelitian

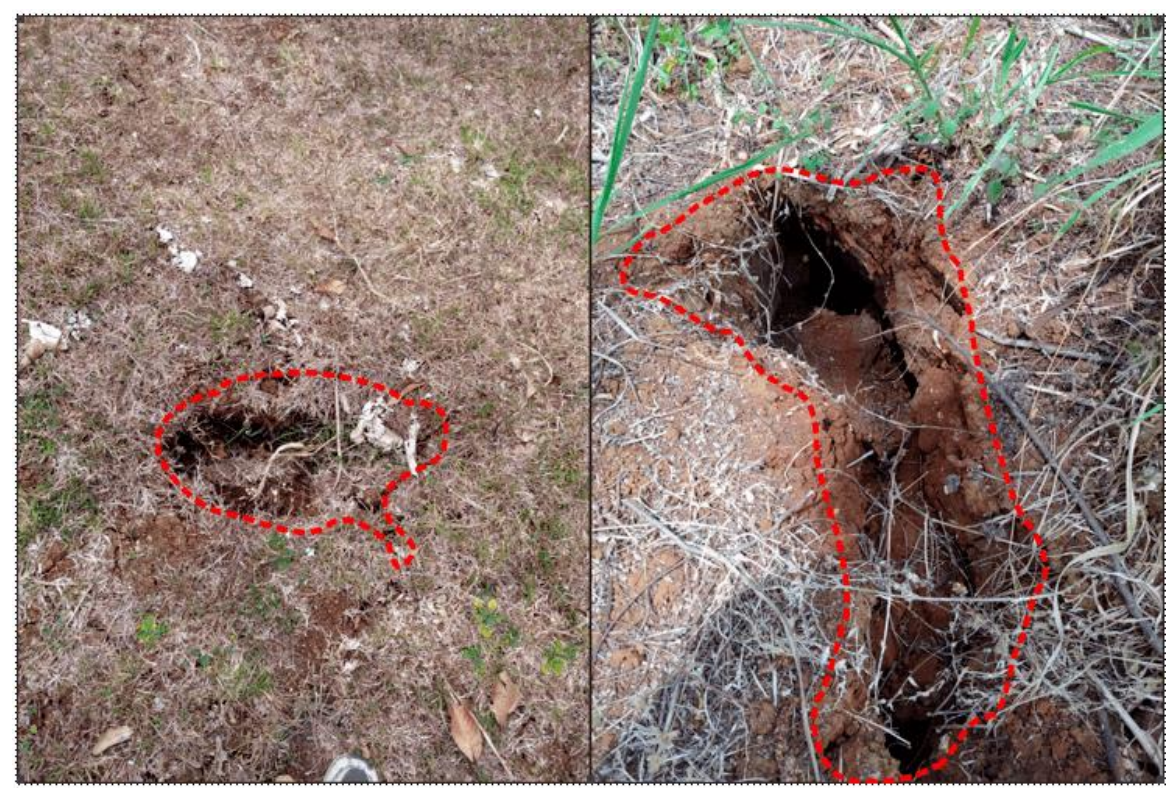

Gambar 11. Rekahan pada permukaan ditengarai sebagai indikasi dan gejala terjadinya proses amblesan

\section{KESIMPULAN}

Berdasarkan hasil analisis dan interpretasi terhadap data geologi permukaan dan geofisika dengan metode geolistrik, dapat disimpulkan bahwa daerah penelitian memiliki kondisi morfologi bergelombang lemah denudasional, perbukitan tersayat kuat karst, perbukitan bergelombang kuat karst dengan litologi penyusunya didominasi oleh batuan karbonat berupa batugamping berlapis maupun batugamping terumbu dan juga ada batuan piroklastik (tuf) pada lokasi tertentu dan juga memiliki struktur geologi berupa sesar naik. Pada daerah penelitian di Desa Bedoyo dan sekitarnya memiliki 2 (dua) jenis tipe amblesan berdasarkan genesanya yaitu: tipe dropout sinkhole dan suffosion sinkhole. Selain itu, ada amblesan dengan tipe suffosion sinkhole yang dipengaruhi oleh struktur geologi berupa sesar naik. Kondisi bawah 
permukaan pada lokasi penelitian berdasarkan hasil kajian geolistrik dapat diinterpretasikan adanya zona-zona rongga (cavity zones) yang diduga sebagai pemicu amblesan di permukaan. Hasil dari pemodelan geologi dan amblesan di daerah enelitian didaptkan hasil berupa zona rawan amblesan yang terbagi menjadi 3 zona yaitu zona rawan yang mencakup Desa Sigorejo, Gombong, Pucanganom dan Desa Bedoyo, zona Sedang mencakup Desa Sumbergiri dan Desa Karangasem, sedangkan untuk wilayah zona rendah mencakupa daerah dusun Asem Lulang.

\section{UCAPAN TERIMAKASIH}

Penulis mengucapkan terimakasih kepada Dirjen Belmawa Kemenristekdikti selaku pemberi dana penelitian dan kepada Institut Teknologi Nasional Yogyakarta yang telah membantu pendanaan penelitian.

\section{DAFTAR PUSTAKA}

Abidin, H.Z., Andreas, H., Gumilar, I., Sidiq, T. P., dan Fukuda, Y. (2013), Land Subsidence in Coastal City of Semarang (Indonesia): Characteristics, Impacts and Causes. Geomatics, Natural Hazards and Risk, 4(3), 226240. DOI: $10.1080 / 19475705.2012 .692336$.

Arbiyakto, D. dan Kadaryanto, D. (2002), Identifikasi Pengukuran Kerugian Fisik Bangunan Rumah dan Kerugian Sosial Penduduk Kawasan Pantai Kota Semarang. Prosiding Seminar Dampak Kenaikan Muka Air Laut pada Kota-Kota Pantai di Indonesia. Bandung 12-13 Maret 2002. Departemen Permukiman dan Prasarana Wilayah. Badan Penelitian dan Pengembangan Kimpraswil. Pusat Penelitian dan Pengembangan Permukiman.

Aurelia, M. (2016). Penentuan Adanya Rongga-Rongga Pada Daerah Batugamping Menggunakan Metode Geolistrik Konfigurasi Wenner Schlumberger Daerah Batulicin, Kabupaten Tanah Bumbu, Kalimantan Selatan (Doctoral Disertasi). UPN" Veteran" Yogyakarta.

Dunham, R. J. (1962). Classification of Carbonate Rocks according to Depositional Textures.

Embry, A. F., \& Klovan, J. E. (1971). a Late Devonian Reef Tract on Northeastern Banks Island, NWT. Bulletin of Canadian petroleum geology, 19(4), 730-781.

Glopper, R.J., dan Ritzema, H.P., 1994. Land Subsidence, in: Ritzema, H.P., (ed.) Drainage Principles and Applications, International Institute for Land Reclamation and Improvement, The Netherlands, 477-510.

Marfai, M.A. dan King, L. (2008), Coastal Flood Management in Semarang, Indonesia. Environmental Geology, 55, 1507-1518. Springer.

Poland, J. F. (1984). Guidebook to Studies of Land Subsidence due to Ground-Water Withdrawal.

Rizqi, A. H. F. dan Fatimah (2020). Penentuan Batuan Alas dan Penyekat berdasarkan Metode Geolistrik Konfigurasi Dipole-Dipole pada Telaga Gesing, Pucanganom, Kabupaten Gunung Kidul. Prosiding Nasional Rekayasa Teknologi Industri dan Informasi XV

Rizqi, A. H. F. dan Sugarbo, O. (2020). Rekonstruksi Stratigrafi Jalur Sungai Krenceng, Ponjong, Gunung Kidul, Yogyakarta. Prosiding Nasional Rekayasa Teknologi Industri dan Informasi XV

Samodra, H., (2017). Batupasir Kuarsa Wediwutah: Asal Kuarsa dan Informasi Keragaman Geologi Formasi Wonosari, Kabupaten Gunung Kidul. Jurnal Geologi dan Sumberdaya Mineral, 17(2), 73-84.

Setiahadiwibowo, A. P. (2020). Identifikasi Rongga Menggunakan Metode Geolistrik Konfigurasi Dipole-Dipole Daerah Nusakambangan Cilacap Jawa Tengah. KURVATEK, 5(2), 47-54.

Surono, Toha.B., dan Sudarno, (1992). Peta Geologi Lembar Surakarta-Giritontro, Jawa. Pusat Penelitian dan Pengembangan Geologi, Bandung.

Telford, W. M., Telford, W. M., Geldart, L. P., Sheriff, R. E., \& Sheriff, R. E. (1990). Applied geophysics 1. Cambridge University Press.

Van Zuidam, R. A. (1979). Terrain Analysis and Classification Using Aerial Photographs: A Geomorphological Approach (No. 526.982 V3).

Waskita, R. S. A., \& Wijayanti, H. K. (2020). Studi Provenance dan Analisis Granulometri Endapan Pasir di Daerah Tambakromo, Ponjong, Gunung Kidul, Daerah Istimewa Yogyakarta. Geoda, 1(1), 35-49.

Widyaningtyas, C.P., Widyaningtyas, C.P., Putra, D.P.E. and Putra, D.P.E., (2014), October. Pemetaan Bahaya Amblesan di Daerah Karst Kecamatan Semanu, Kabupaten Gunung Kidul, Propinsi Daerah Istimewa 
Yogyakarta. Prosiding Seminar Nasional Kebumian Ke-7 Jurusan Teknik Geologi, Fakultas Teknik, Universitas Gadjah Mada, 30-31 Oktober 2014. Jurusan Teknik Geologi.

Yudhana, W. M. B., Uligawati, G. W., \& Basri, R. R. (2020). Penyelidikan Geolistrik Menggunakan Konfigurasi Schlumberger Terhadap Potensi Amblesan Daerah Ponjong, Gunung Kidul. KURVATEK, 5(2), 31-40.

Zubaidah, T. and Kanata, B., (2008). Pemodelan Fisika Aplikasi Metode Geolistrik Konfigurasi Schlumberger untuk Investigasi Keberadaan Air Tanah. J Teknik Elektro, 7(1), 20-24. 